\title{
Upaya Penanggulangan Penyebaran Paham Radikalisme pada Santri Blitar
}

\author{
Soebiantoro', Sulistyo Anjarwati ${ }^{2}$, Farkhan Evendi ${ }^{3}$ \\ 1,2,3 Ilmu Administrasi Negara, Universitas Islam Balitar, J1. Majapahit No.2- 4, Kota Blitar, Indonesia, 66137
}

Correspondence: soebiantoro@unisbablitar.ac.id

Received: 30 Juni 2021 - Revised: 01 Agustus 2021 - Accepted: 16 Agustus 2021

\begin{abstract}
Abstrak. Tujuan dilakukannya pengabdian kepada masyarakat melalui sosialisasi upaya penanggulangan paham radikalisme pada santri di Blitar adalah untuk memberikan pengetahuan tentang proses pencegahan radikalisme di kalangan santri. Ruang lingkup kegiatan pengabdian meliputi pemberian sosialisasi tentang paham radikalisme dan terorisme yang mengancam NKRI utamanya para santri. Kegiatan ini merupakan upaya preventif untuk membentengi para mahasiswa yang menjadi santri di Pondok Pesantren Tarbiyatus Sholihin Kuningan Kanigoro Blitar. Hasil kegiatan pengabdian kepada masyarakat dapat disimpulkan bahwa terdapat beberapa hal yang perlu disadari mengenai peyebaran radikalisme yaitu para pegiat dan pendukung gerakan radikalisme selalu berupaya memperbaharui modus penyebarannya. Secara keseluruhan kegiatan pengabdian kepada masyarakat melalui sosialisasi upaya penanggulangan penyebaran paham radikalisme pada santri di Pondok Pesantren Tarbiyatus Sholihin berjalan dengan lancar.
\end{abstract}

Kata kunci: Penanggulangan, penyebaran, radikalisme, santri

Citation Format: Soebiantoro, Anjarwati, S. \& Evendi, F. (2021). Upaya Penanggulangan Penyebaran Paham Radikalisme pada Santri Blitar. Prosiding Seminar Nasional Abdimas Ma Chung (SENAM), 2020, 120-128. 


\section{PENDAHULUAN}

Di era sekarang ini banyak sekali gerakan-gerakan yang mengatasnamakan keagamaan berseliweran di berbagai Negara. Agama yang seringkali dikaitkan dengan kelompok radikal adalah agama Islam. Radikalisme sendiri merupakan suatu paham yang telah menyebar di lingkungan global, nasional, maupun local. Radikalisme dipahami sebagai gerakan revolusi yang menginginkan adanya perubahan baik pada system politik, social maupun ekonomi di suatu Negara. Pergerakan gerakan radikalisme umunya bertindak menggunakan simbol-simbol agama serta alat-alat kekerasan. Gerakan radikal seringkali mengatasnamakan agama sebagai dasar dari kegiatan yang mereka lakukan. Kelompok ini menginginkan integrasi dalam Islam dan membentuk Negara Islam. Paham radikalisme muncul dikarenakan terdapat pengkaliman pemahaman tunggal dan kesalahan interpretasi terhadap ajaran Islam. Pada dasarnya paham radikalisme sangat berseberangan dengan ajaran Islam yang damai.

Persoalan-persoalan tersebut bermuara pada ideologi radikalisme yang ingin merubah tatanan bangsa Indonesia yang jelas bertentangan dengan Pancasila. Gerakan radikalisme sebagai suatu faham tidak selalu ditandai dengan aksi-aksi kekerasan, namun dapat juga sebatas ideologi yang tidak menggunakan cara-cara kekerasan (Khamdan, 2016). Gerakan ini sebenarnya masuk kedalam kategori gerakan yang berbahaya yang seringkali menimbulkan rasa tidak nyaman bagi masyarakat lainnya. Karena biasanya dalam perwujudan gerakan paham ini mereka menggunakan cara-cara ekstrim seperti melakukan teror, memberikan ancaman dan bahkan kekerasan, serta menyebarkan doktrin-doktrin ekstrim Islam lainnya (Tangirerung, 2018).

Penyebarana paham radikalisme dapat dilihat dari beberapa factor, beberapa factor yang dipercayai masyarakat sebgai factor yang dapat menjadi pendorong terbentuknya radikalisme pada suatu individu maupun kelompok adalah kepercayaan, latar belakang pendidikan, kondisi social, lingkungan dan ekonomi. Opini yang beredar di masyarakat mengaitkan bahwa actor radikalisme diarahkan kepada sekelompok orang yang terdidik dari pondok pesantren atau santri pondok pesantren. Dengan munculnya opini ini tentunya pesantren mendapatkan citra buruk karena adanya anggapan bahwa pesantren merupakan tempat pendidikan bagi calon teroris dan sebagai penyebar paham radikalisme. 
Radikalisme yang berkembang di tengah masyarakat baik dalam bentuk radikalisme ideology maupun radikalisme agama harus dapat dicegah. Hal ini diperlukan untukmenciptakan masyarakat yang rukun dan harmonis. Untuk melakukan upaya penanggualangan dan pencegahan radikalisme bukanlah hal yang mudah dan membutuhkan strategi yang terstruktur, tersistem dan massif. Karena hal tersebut penting adanya pemahaman yang komprehensif tentang gerakan radikalisme dan melakukan pencegahan terhadap gerakan radikalisme tersebut melalui pemberian pemahaman mengenai radikalisem dan upaya penaggulangannya.

Timbulnya masalah radikalisme dikalangan para santri harus diantisipasi dengan pendekatan yang sistematik dan strategis melalui jalur dialog serta edukasi. Dalam buku Studi Islam Kontemporer karya Syamsul Arifin dikatakan bahwa arus radikalisme di Indonesia mencatat perlu adanya optimalisasi peran lembaga pendidikan, termasuk perguruan tinggi, dalam mencegah dan menawarkan solusi alternative gerakan paham radikalisme negative atau deradikalisasi melalui jalur dialog dan edukasi (Huda, Haryanto \& Setyo, 2018). Pada intinya, pencegahan dini dari praktik radikalisme negative bisa dilakukan dengan diberikannya penguatan kembali kegiatan edukatif yang kreatif, inovatif, produktif, dan kooperatif berbasis empat pilar kebangsaan yaitu Pancasila, UUD 1945, NKRI, dan Bhineka Tunggal Ika.

\section{MASALAH}

Mahasiswa menjadi sasaran rekrutmen kelompok karena dalam fase ini mahasisiwa paling mudah dipengaruhi tanpa melalui pendalaman keilmuan yang sebenarnya. Sehingga seringkali mahasiswa menerima paham tanpa menyaringnya terlebih dahulu. Pemahaman nilai-nilai keagamaan mahasiswa yang mendalam adalah yang diperlukan untuk meluruskan pemikiran-pemikiran yang menyesatkan. Jadi konsep bela Negara dapat juga diwujudkan dalam bentuk pemantapan nilai-nilai keagamaan pada mahasisiwa untuk mencegah pemikiran-pemikiran radikalisme yang mengatasnamakan agama mempengaruhi mahasiswa. Langkah-langkah bisa diambil bisa melalui bidang dakwah berupa langkahlangkah afirmasi nilai-nilai ahlussunah wal jamaah an-nahdliyah sekaligus untuk menegasi faham-faham radikal di masyarakat terutama melalui program kaderisasi yang intensif. Mewujudkan budaya dan peradaban yang beradab, toleransi, harmoni dan cinta damai dengan berperan serta dalam mewujudkan harmonisasi kehidupan beragama dalam level global. 
Di bidang pendidikan khususnya Pondok Pesantren yang didalamnya terdiri dari mahasiswa/i dari berbagai perguruan tinggi dituntut untuk dapat mengarahkan pemantapan nilai-nilai keagamaan pada santri agar dapat mencegah masuknya paham-paham radikalisme yang mempengaruhi pemikiran santri. Selain nilai keagamaan pembaharuan kurikulum yang seimbang antara substansi agama dan keduniawian guna membentuk generasi yang berpandangan luas, teguh pada jati diri bangsa dan mandiri juga diperlukan. Berdasarkan hal tersebut tujuan dilakukannya pengabdian kepada masyarakat melalui sosialisasi upaya penanggulangan paham radikalisme pada santri di Blitar adalah untuk memberikan pengetahuan tentang proses pencegahan radikalisme di kalangan santri.

\section{METODE PELAKSANAAN}

Ruang lingkup kegiatan pengabdian meliputi pemberian sosialisasi tentang paham radikalisme dan terorisme yang mengancam NKRI. Kegiatan ini merupakan upaya preventif untuk membentengi para mahasiswa yang menjadi santri di Pondok Pesantren Tarbiyatus Sholihin Kuningan Kanigoro Blitar. Kegiatan ini bertujuan agar membentuk kesadaran kritis pada generasi muda sehingga mampu membedakan paham-paham apa saja yang sehaluan dengan NKRI. Jika para generasi muda sudah mampu memahami maka niscaya akan mampu membentengi diri dan tidak terpengaruh oleh paham-paham tersebut.

Metode pelaksanaan kegiatan dalam pengabdian kepada masyarakat ini meliputi langkah-langkah sebagai berikut :

1. Penentuan peserta, dalam tahapan ini anggota pengabdian memilih peserta yang dinilai sangat memerlukan pemberian materi mengenai penanggulangan penyebaran radikalisme.

2. Penyampaian materi, dalam tahapan ini anggota pengabdian menyampaikan materi mengenai upaya penanggulangan paham radikalisme.

3. Tanya jawab

\section{HASIL DAN PEMBAHASAN}

Kegiatan pengabdian kepada masyarakat melalui sosialisasi upaya penanggualangan penyebaran paham radikalisme pada santri Blitar dilakukan di Pondok Pesantren Tarbiyatus Sholihin pada hari Minggu, 20 Juni 2021 jam 09.00-10.00 WIB. Kegiatan ini bertujuan untuk memberikan pemahaman kepada para santri mengenai gerakan radikalisme di Indonesia, indikasi radikalisme di masyarakat, dan langkah-langkah yang 
dilakukan apabila terjadi gerakan radikalisme atau terdapat tanda mencurigakan dari orangorang yang dicurigai terindikasi gerakan radikalisme.

Kegiatan ini diawali dengan sambutan yang diberikan oleh kepala Pondok Pesantren yaitu Bapak Rochmad Khudlori. Kemudian dilanjutkan dengan pemberian materi terkait upaya penanggunalan penyebaran radikalisme. Beberapa hal yang disampaikan dalam kegiatan pengabdian tersebut antara lain yaitu potendi radikalisme yang ditentukan oleh persepsi individu yang tentunya tidak hanya dipengaruhi oleh landasan ideology tertentu, akan tetapi juga dapat dipengaruhi oleh factor lainnya, baik factor regional maupun global (Hilmy, 2015). Akan tetapi gerakan radiklisme seperti tindakan teroris juga dilandasi dengan adanya pemahaman ideology yang radikal, artinya radikalisme bida dalam bentuk ideology yang bertentangan dengan pilar kebangsaan Indonesia atau aksi yang merusak tatanan masyarakat. Modal awal seseorang dapat menjadi pelaku teroris adalah potensi berpikir dan bersikap radikal, kemudian berideologi radikalisme dan akhirnya tumbuh reaktif menjadi radikalisasi (Rokhmad, 2012).

Setelah diberikannya penjelasan mengenai pengertian dari radikalisme disampaikan juga materi mengenai terorisme. Terorisme merupakan tindakan kejahatan terhadap kemanusiaan dan peradaban yang menimbulkan ancaman serius terhadap kedaulatan Negara, berbahaya bagi keamanan, perdamaian dunia serta merugikan kesejahteraan msyarakat. Terorisme merupakan salah satu bentuk dari kejahatan yang diorganisasi dengan baik, bersifat transasional dan digolongkan sebagai kejahatan luar biasa yang tidak membeda-bedakan sasaran.

Terdapat perbedaan antara gerakan terorisme dan jihad. Diantara perbedaan tersebut yaitu terorisme sifatnya merusak dan anarkis yang tujuannya menciptakan rasa takut atau mengancam pihak lain. Tindakan teroris dilakukan tanpa aturan dan sasaran terorisme yaitu tak terbatas. Sedangkan jihad mengandung pemahaman bahwa sifatnya melakukan suatu perbaikan meskipun harus menggunakan cara peperangan dan tujuannya yaitu menegakkan agama Allah atau membela hak-hak pihak yang terzhalimi. Kemudian tindakan jihad dilakukan dengan mengikuti aturan yang ditentukan oleh syari'at dengan sasaran musuh yang jelas.

Gerakan radikalisme harus terus diwaspadai karena memiliki agenda terselubung yang mampu menggerogoti nilai-nilai Pancasila hingga dapat memecah belah bangsa 
Indonesia. Gerakan radikalisme ummumnya dilakukan oleh orang-orang yang tergabung di kelompok Negara Islam Suriah dan Irak (ISIS), Gafatar, dan lainnya. Melawan radikalisme bukan hanya dapat dilakukan dengan cara kekerasan, karena yang dihadapi adalam masalah ideology yang diyakini, sehingga juga harus ditangani dengan memberikan pemahaman ke jalan yang benar.

Setelah pemaparan materi selesai disampaikan dalam kegiatan pengabdian kepada masyarakat, peserta pengabdian dapat mempelajari dan mengkaji gerakan radikalisme secara baik, dan menjadi garda terdepan jika ada indikasi-indikasi gerakan radikalisme di desa tempat tinggalnya.

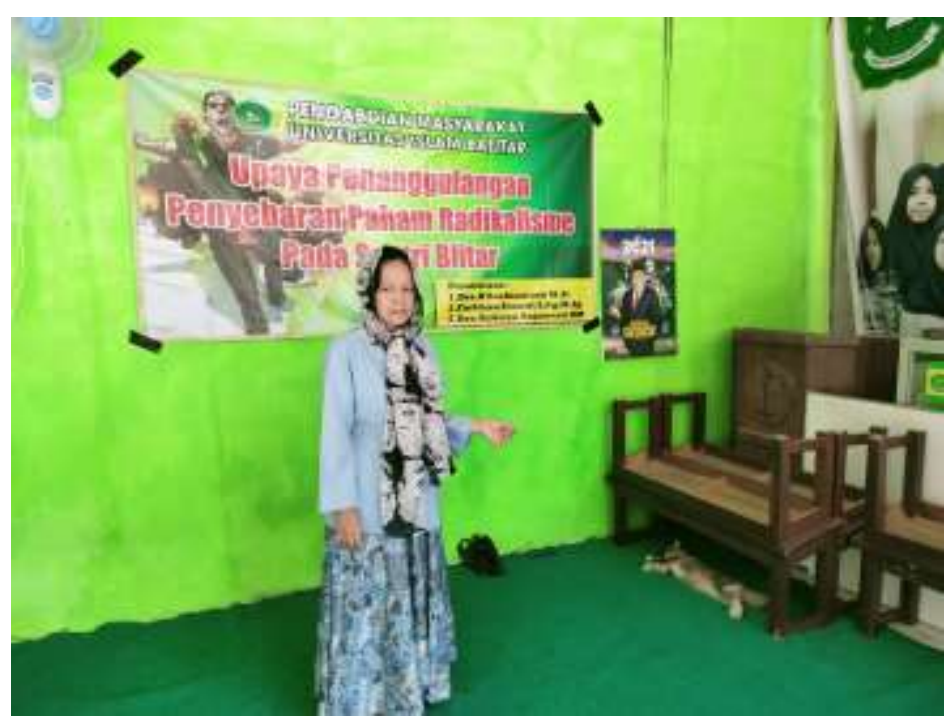

Gambar 1. Penyampaian materi

Kemudian tahapan selanjutnya dalam kegiatan pengabdian kepada masyarakat yaitu tahapan tanya jawab. Peserta pengabdian mengajukan pertannyaan terkait dengan materi yang ditanyakan salah satunya yaitu pertanyaan mengenai tindakan yang dilakukan masyarakat ketika muncul tindakan radikalisme. Kemudian pertanyaan tersebut dijawab oleh narasumber dalam kegiatan pengabdian kepada masyarakat yaitu dalam menyelesaikan fenomena munculnya gagasan dan tindakan radikal, ekstrem, dan teror di Indonesia masih terjadi pelanggaran-pelanggaran Hak Asasi Manusia (HAM). Dalam penelitian Satriawan, Islami, \& Lailam (2019) dijelaskan bahwa peninggalan gagasan dan tindakan radikal, ekstrem, dan teror dapat mengindahkan HAM dan berpegang pada prinsip due of law dan asas praduga tak bersalah. 
Setelah kegiatan tanya jawab selesai tahapan selanjutnya dalam pengabdian yaitu pembagian stiker yang dilakukan oleh anggota tim pengabdian. Stiker tersebut berisi mengenai lima poin deklarasi penolakan radikalisme dikalangan mahasiswa.

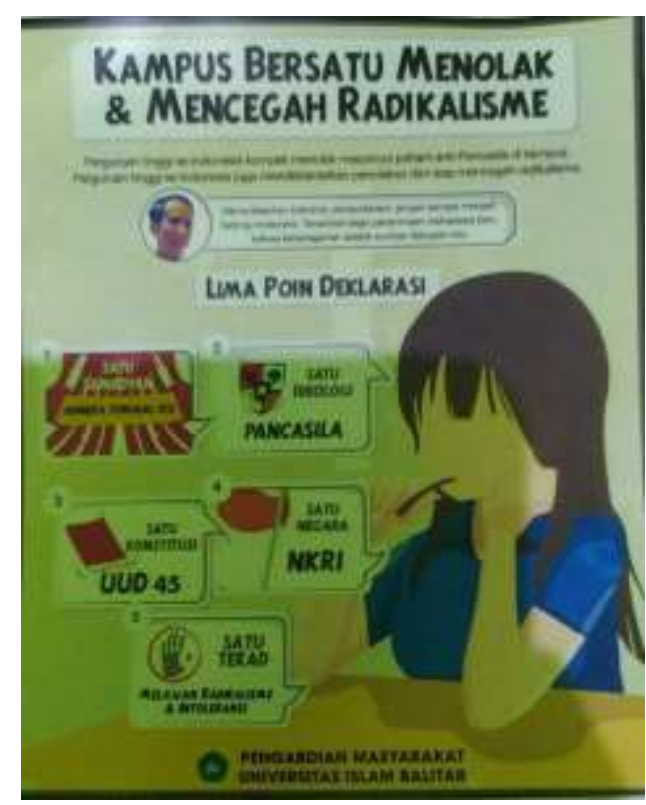

Gambar 2. Stiker penolakan radikalisme

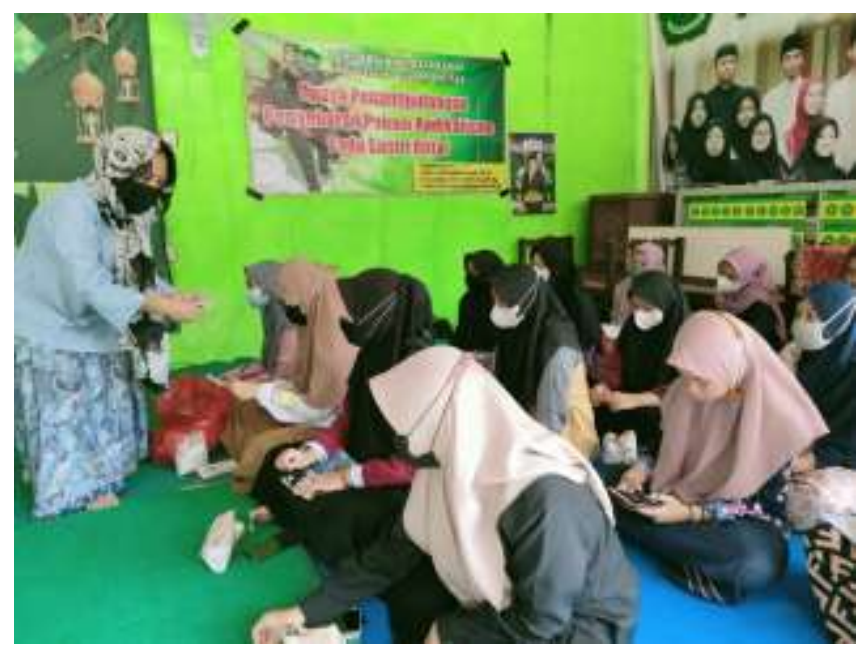

Gambar 3. Pembagan stiker penolakan radikalisme

Secara keseluruhan kegiatan pengabdian kepada masyarakat melalui sosialisasi upaya penanggulangan penyebaran paham radikalisme pada santri di Pondok Pesantren Tarbiyatus Sholihin berjalan dengan lancar. Para peserta sangat antusias mengikuti kegiatan yang dilaksanakan dan peserta juga aktif bertanya apabila ada materi yang kurang dipahami. Peserta juga mengungkapkan jika kegiatan seperti ini dapat menambah wawasan 
bagi santri utamanya santri Pondok Pesantren yang juga merupakan mahasiswa di Perguruan Tinggi.

\section{KESIMPULAN}

Kegiatan pengabdian kepada masyarakat dengan judul "upaya penanggulangan penyebaran paham radikalisme pada santri Blitar" merupakan kegiatan sosialisasi yang dilakukan oleh Dosen Universitas Islam Balitar di Pondok Pesantren Tarbiyatus Sholihin. Berdasarkan pemaparan hasil kegiatan di atas dapat disimpulkan bahwa terdapat beberapa hal yang perlu disadari mengenai peyebaran radikalisme yaitu para pegiat dan pendukung gerakan radikalisme selalu berupaya memperbaharui modus penyebarannya. Bahkan ideology radikalisme dikemas dengan sedemikian rupa untuk agar dapat menarik pengikutpengikut baru. Oleh karena itu, perlu kewaspadaan yang tinggi melalui peningkatan kegiatan pemberian pemahaman agama Islam sebagaimana disampaikan oleh Allah SWT. Dan Rasul-Nya.

\section{UCAPAN TERIMA KASIH}

Terimakasih kami sampaikan kepada Universitas Islam Balitar yang telah mendanai kegiatan ini. Tak lupa kami sampaikan terimakasih kepada keseluruhan anggota yang turut ikut membantu kegiatan pengabdian ini.

\section{DAFTAR PUSTAKA}

Hilmy, M. (2015). Radikalisme Agama dan Politik Demokrasi di Indonesia Pasca Orde Baru. Jurnal MIQAT, 39(2), 407-425.

Huda, U., \& Haryanto, T. (2018). Strategi Penanggulangan Radikalisme Di Perguruan Tinggi Kabupaten Banyumas. An-Nidzam: Jurnal Manajemen Pendidikan dan Studi Islam, 5(1), 39-61.

Khamdan, M. (2016). Pengembangan Nasionalisme Keagamaan Sebagai Strategi Penanganan Potensi Radikalisme Islam Transnasional. Addin, 10(1), 207-232.

Rokhmad, A. (2012). Radikalisme Islam dan upaya deradikalisasi paham radikal. Walisongo: Jurnal Penelitian Sosial Keagamaan, 20(1), 79-114.

Satriawan, I., Islami, M. N., \& Lailam, T. (2019). Pencegahan Gerakan Radikalisme melalui Penanaman Ideologi Pancasila dan Budaya Sadar Konstitusi Berbasis Komunitas. Jurnal Surya Masyarakat, 1(2), 99-110.

Tangirerung, J. R. (2018). Peningkatan Pemahaman Pluralisme Agama dalam Rangka Mereduksi Radikalisme. Kinaa Jurnal Teologi, 4(2). 


\section{(c) (1)}

(C) 2021 by authors. Content on this article is licensed under a Creative Commons Attribution 4.0 International license. (http://creativecommons.org/licenses/by/4.0/). 